University of Nebraska - Lincoln

DigitalCommons@University of Nebraska - Lincoln

Publications, Agencies and Staff of the U.S.

Department of Commerce

U.S. Department of Commerce

$1-2005$

\title{
Implantation of Subcutaneous Radio Transmitters in the Harbor Seal (Phoca vitulina)
}

\author{
Michelle Lander \\ Marine Mammal Center, Marin Headlands \\ Martin Haulena \\ Marine Mammal Center, Marin Headlands \\ Frances Gulland \\ Marine Mammal Center, Marin Headlands \\ James Harvey \\ Moss Landing Marine Laboratories, 8272 Moss Landing Road, Moss Landing, California
}

Follow this and additional works at: https://digitalcommons.unl.edu/usdeptcommercepub

Part of the Environmental Sciences Commons

Lander, Michelle; Haulena, Martin; Gulland, Frances; and Harvey, James, "Implantation of Subcutaneous Radio Transmitters in the Harbor Seal (Phoca vitulina)" (2005). Publications, Agencies and Staff of the U.S. Department of Commerce. 193.

https://digitalcommons.unl.edu/usdeptcommercepub/193

This Article is brought to you for free and open access by the U.S. Department of Commerce at DigitalCommons@University of Nebraska - Lincoln. It has been accepted for inclusion in Publications, Agencies and Staff of the U.S. Department of Commerce by an authorized administrator of DigitalCommons@University of Nebraska - Lincoln. 


\title{
IMPLANTATION OF SUBCUTANEOUS RADIO TRANSMITTERS IN THE HARBOR SEAL (PHOCA VITULINA)
}

\author{
Michelle E. LANDER ${ }^{1}$ \\ Martin Haulena \\ Frances M. D. Gulland
}

The Marine Mammal Center, Marin Headlands, 1065 Fort Cronkhite, Sausalito, California 94965, U.S.A.

E-mail: michelle.lander@noaa.gov

James T. Harvey

Moss Landing Marine Laboratories, 8272 Moss Landing Road, Moss Landing, California 95039, U.S.A.

Radio telemetry has become a standard tool for studying the behavior, physiology, life history traits, and population dynamics of marine mammals. Radio transmitters typically are attached to the hind flippers of pinnipeds or glued to the fur using marine epoxy or other cyanocrylate adhesives (Fedak et al. 1983, Bengtson 1993, Jeffries et al. 1993). Longterm data acquisition is difficult, however, because radio-flipper transmitters commonly tear from the webbing of the flipper and instruments that are glued to the fur are shed during the seasonal molt.

Internal radio transmitters have the advantage of remaining intact and functioning longer than traditional attachments. Implanted transmitters also are protected from extrinsic variables such as environmental elements and wear (Eagle et al. 1984). Although subcutaneous and intraperitoneal radio transmitters have been used successfully in birds (Petersen et al. 1995), polar bears (Ursus maritimus; Mulcahy and Garner 1999), and several mustelids (Eagle et al. 1984, Hoover 1984, Reid et al. 1986, Spelman et al. 1997, Stoskopf et al. 1997, Johnson and Berkley 1999, Hernandez-Divers et al. 2001), including sea otters (Enhydra lutris; Garshelis and Siniff 1983, Williams and Siniff 1983, Ralls et al. 1989), they have not been used successfully in pinnipeds. Attempts to implant radio transmitters in pinnipeds during the late 1960 s and early 1980 s were largely unsuccessful. ${ }^{2}$ Previous surgical implantation in pinnipeds has been hampered by excessive tissue reaction, infection, and subsequent rejection of implanted materials. However, we believed that the use of improved transmitter and monofilament suture materials, coupled

\footnotetext{
${ }^{1}$ Current address: National Marine Mammal Laboratory, National Marine Fisheries Service, 7600 Sand Point Way N.E., Seattle, Washington 98115, U.S.A.

${ }^{2}$ Personal communication from R. L. DeLong, National Marine Mammal Laboratory, F/AKC3, 7600 Sand Point Way NE, Seattle, WA 98115, U.S.A., May 2003.
} 
with proper surgical techniques, would limit wound breakdown and improve the healing process. The objectives of this study were to examine the feasibility of implanting subcutaneous VHF transmitters in rehabilitated and free-ranging harbor seals (Pboca vitulina richardii), and to evaluate success by monitoring their postrelease survival.

Four different transmitter models, which varied in shape and size, were used (IMP/200/L and IMP/300/L models configured by Telonics, Mesa, AZ, and Subcu $16 \mathrm{M}-3 \mathrm{v}$ and Bodylmp $16 \mathrm{M}-3 \mathrm{v}$ models by Advanced Telemetry Systems, Isanti, $\mathrm{MN})$. The IMP $/ 200 / \mathrm{L}(6.1 \times 2.3 \mathrm{~cm}, 25 \mathrm{~g})$ and IMP $/ 300 / \mathrm{L}(8.2 \times 2.2 \mathrm{~cm}, 40 \mathrm{~g})$ transmitters were cylindrically shaped, internally cast (Hysol Cast 3), and encased in a high impact plastic shell that was covered with a physiologically compatible Paraplast ${ }^{\circledR}$ wax coating, whereas the Subcu $16 \mathrm{M}-3 \mathrm{v}(8.3 \times 2.5 \times 0.9 \mathrm{~cm}, 41 \mathrm{~g})$ and BodyImp $16 \mathrm{M}-3 \mathrm{v}(5.0 \times 2.5 \times 1.0 \mathrm{~cm}, 27 \mathrm{~g})$ transmitters were flatter and encased in an inert resin. The BodyImp $16 \mathrm{M}-3 \mathrm{v}$ had a whip antenna $(30.5 \mathrm{~cm})$ that was external to the transmitter, whereas the other three models had coiled antennas $(30.5 \mathrm{~cm}$ ) that were completely self-contained (Fig. 1). All transmitters were equipped with temperature mortality sensors, operated at 30 pulses per minute, and were duty-cycled ( $8 \mathrm{~h}$ on, $16 \mathrm{~h}$ off) to achieve an approximate life span of $3 \mathrm{yr}$.

We determined the "line of sight" range for three of the four transmitters along a roadway void of obstructions that could produce signal bounce (Table 1). All surgical procedures were first tested on dead harbor seals to determine the best location for the transmitter. We implanted transmitters between the blubber and subcutaneous muscle layers to prevent migration. To avoid interference with musculo-skeletal motion and to optimize exposure at the sea surface, we implanted transmitters on the left dorsal thorax, approximately $10 \mathrm{~cm}$ lateral to the spine and $5 \mathrm{~cm}$ caudal to the scapula. We also chose this site for implantation because pups would be unable to open sutures on this part of the body.

During the summer of 2000 , four newly weaned, rehabilitated harbor seal pups that were undergoing treatment at The Marine Mammal Center (TMMC), Sausalito, California, were selected for this study (Table 2). Seals chosen for surgery were clinically stable, but not ready for release (i.e., insufficient mass gain), such that postoperative monitoring in captivity was possible. Before implantation, seals were fasted the night before surgery $(12 \mathrm{~h})$. Additionally, transmitters were coldsterilized in glutaraldehyde (Cidex, Johnson \& Johnson Co., Irvine, CA) for $1 \mathrm{~h}$ and then thoroughly rinsed with normal saline to remove any toxic residue (HernandezDivers et al. 2001). Seals were anesthetized approximately $10 \mathrm{~min}$ after atropine premedication $(0.02 \mathrm{mg} / \mathrm{kg}$ IM) by masking them with isoflurane. Seals were further anesthetized and intubated using techniques described in Haulena and Heath (2001). During surgery, heart and respiratory rates, end-tidal carbon dioxide, oxygen saturation of hemoglobin, and temperature were monitored. A $10 \times 7 \mathrm{~cm}$ patch of hair was shaven at the designated incision site detailed above and sterilized using routine surgical preparation. A vertical skin incision ( $\sim 6$ to $8 \mathrm{~cm}$ ) was made in the center of the shaven patch using a scalpel blade. The underlying blubber layer $(\sim 3 \mathrm{~cm}$ thick) was incised and the transmitter was inserted beneath the blubber layer over the superficial cutaneous trunci muscle and positioned parallel to the longitudinal axis of the seal to minimize stresses on the implant from body 


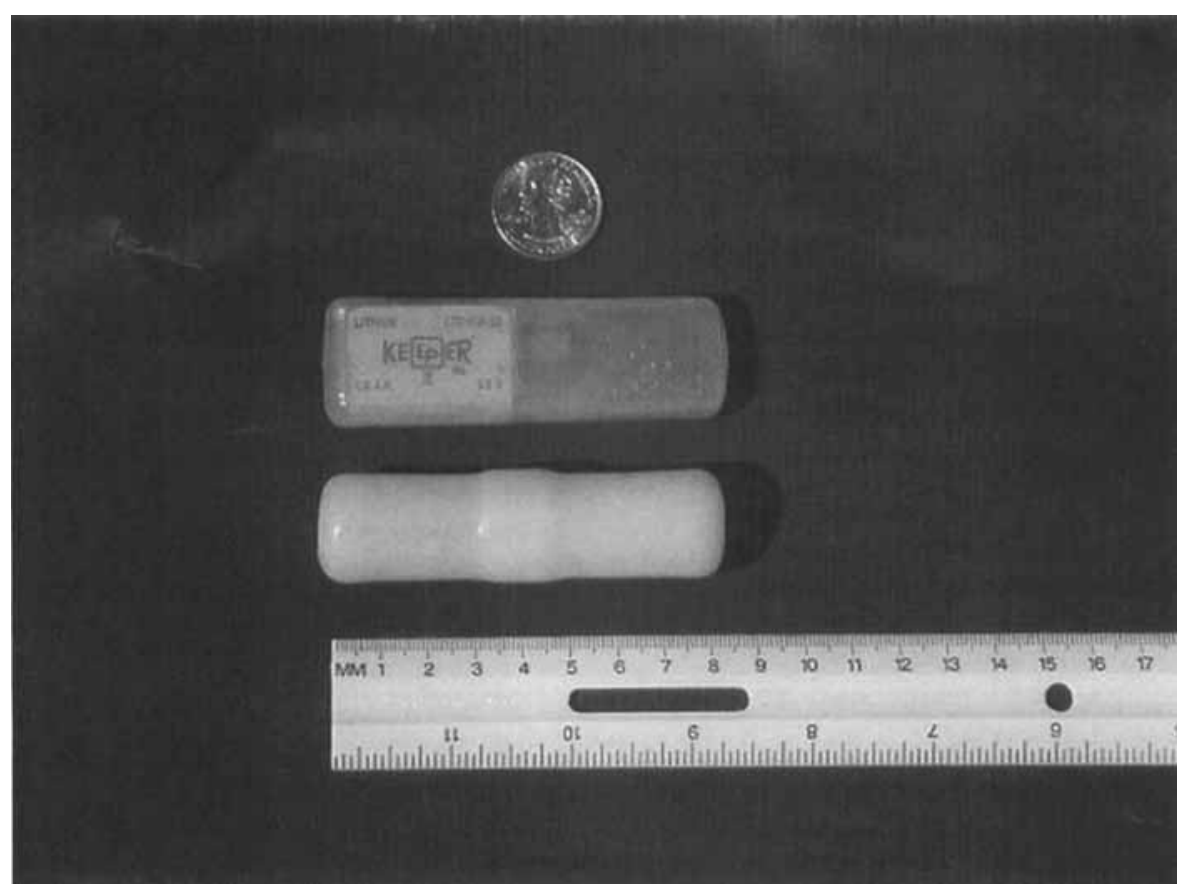

Figure 1. Subcu 16M-3v (top) and IMP/200/L (bottom) transmitters implanted in captive harbor seals during 2000. The IMP/300/L (not shown here) was slightly larger than the IMP/200/L.

movement. Although not tested experimentally, we recommend that the antenna be oriented toward the head of the animal for better signal reception while at sea, in the event the animal displays bottling behavior at the surface. A laparoscopic instrument was used to thread the antenna under the blubber of the animal that was implanted with the Bodylmp 16M-3v transmitter. The incisions were sutured in a four-layer closure using 3-0 PDS II monofilament absorbable sutures (Ethicon, Inc., Somerville, NJ) within the deep subcutaneous tissue and fascia (including subdermal fat) and 2-0 PDS II for the subcuticular tissue and skin. Cyanocrylate

Table 1. Line of sight (LOS) ranges $(\mathrm{km})$ established on land for four transmitter models before and after implantation. Aerial ranges were estimated off the wing, nose, and tail of the aircraft.

\begin{tabular}{lcccccc}
\hline \hline & \multicolumn{5}{c}{ Range $(\mathrm{km})$} \\
\cline { 2 - 7 } \multicolumn{1}{c}{ Model } & \multicolumn{2}{c}{ Land (LOS) } & & Air & \\
\cline { 2 - 7 } \cline { 5 - 7 } & Alone & Implanted & & Wing & Nose & Tail \\
\hline IMP/200/L & - & 0.8 & 8.7 & 2.6 & 3.5 \\
IMP/300/L & 0.5 & 0.5 & 12.6 & 5.2 & 6.3 \\
Subcu 16M-3v & 0.5 & 0.5 & 0.9 & 0.9 & 1.3 \\
BodylmP 16M-3v & 0.8 & 0.5 & & 0.9 & 0.9 & 1.3 \\
\hline
\end{tabular}


Table 2. Characteristics of seals implanted with radio transmitters.

\begin{tabular}{cccccrr}
\hline \hline $\begin{array}{c}\text { Seal } \\
\text { ID }\end{array}$ & Sex & $\begin{array}{c}\text { Release } \\
\text { mass }(\mathrm{kg})\end{array}$ & $\begin{array}{c}\text { Release standard } \\
\text { length }(\mathrm{cm})\end{array}$ & \multicolumn{1}{c}{$\begin{array}{c}\text { Implant } \\
\text { date }\end{array}$} & \multicolumn{1}{c}{$\begin{array}{c}\text { Release } \\
\text { date }\end{array}$} & \multicolumn{1}{c}{$\begin{array}{c}\text { Last } \\
\text { date located }\end{array}$} \\
\hline 2000 & & & & & & \\
1349 & $\mathrm{M}$ & 29.25 & 79.0 & $6 / 6 / 2000$ & $8 / 9 / 2000$ & $11 / 19 / 2000^{\mathrm{b}}$ \\
1360 & $\mathrm{~F}$ & 27.20 & 78.0 & $7 / 14 / 2000$ & $8 / 9 / 2000$ & $8 / 18 / 2000^{\mathrm{b}}$ \\
1391 & $\mathrm{~F}$ & 22.50 & 74.5 & $8 / 3 / 2000$ & $10 / 2 / 2000$ & $10 / 2 / 2000$ \\
1392 & $\mathrm{M}$ & 28.50 & 90.0 & $9 / 6 / 2000$ & $10 / 2 / 2000$ & $10 / 2 / 2000$ \\
2001 & & & & & & \\
1384 & $\mathrm{~F}$ & 60.50 & 135.0 & $2 / 19 / 2001$ & $11 / 4 / 2001$ & $1 / 9 / 2002^{\mathrm{b}}$ \\
1399 & $\mathrm{M}$ & 26.85 & 88.0 & $5 / 31 / 2001$ & $6 / 24 / 2001$ & $4 / 17 / 2003$ \\
1402 & $\mathrm{~F}$ & 25.75 & 90.0 & $5 / 31 / 2001$ & $6 / 24 / 2001$ & $11 / 26 / 2002$ \\
1403 & $\mathrm{M}$ & 25.00 & 98.0 & $6 / 1 / 2001$ & $9 / 9 / 2001$ & $11 / 4 / 2003$ \\
1407 & $\mathrm{M}$ & 34.40 & 90.0 & $6 / 1 / 2001$ & $7 / 14 / 2001$ & $4 / 17 / 2003$ \\
1419 & $\mathrm{M}$ & 24.00 & 92.0 & $7 / 31 / 2001$ & $8 / 15 / 2001$ & $2 / 8 / 2002$ \\
$1104^{\mathrm{a}}$ & $\mathrm{F}$ & 43.00 & 124.0 & $11 / 3 / 2001$ & $11 / 3 / 2001$ & $8 / 31 / 2003$ \\
2002 & & & & & & \\
$140^{\mathrm{a}}$ & $\mathrm{F}$ & 40.00 & 110.0 & $9 / 10 / 2002$ & $9 / 10 / 2002$ & $11 / 4 / 2003$ \\
$160^{\mathrm{a}}$ & $\mathrm{M}$ & 57.00 & 139.0 & $11 / 12 / 2002$ & $11 / 12 / 2002$ & $11 / 4 / 2003$ \\
$180^{\mathrm{a}}$ & $\mathrm{F}$ & 52.00 & 134.0 & $11 / 12 / 2002$ & $11 / 12 / 2002$ & $10 / 12 / 2003$ \\
$200^{\mathrm{a}}$ & $\mathrm{M}$ & 34.00 & 118.0 & $11 / 12 / 2002$ & $11 / 12 / 2002$ & $6 / 17 / 2003$ \\
\hline
\end{tabular}

${ }^{a}$ Wild seal.

b Indicates date of carcass recovery.

topical tissue adhesive (NEXABAND ${ }^{\circledR}$, Abbott Laboratories, Chicago, IL) was applied on the skin surface to seal the incision.

All harbor seals were monitored for $\geq 3 \mathrm{wk}$ before release (Table 2). To mimic tag implantation in the field, harbor seals with implants were immediately returned to their pens (containing a pool and a haul-out site) after recovering from surgery. After surgery, all seals resumed feeding within $24 \mathrm{~h}$. Within $1 \mathrm{wk}$ following surgery, clinical signs, complete blood counts (CBCs), and serum biochemistry values were within normal ranges for three of the four seals (Bossart et al. 2001, Lander et al. 2003). Wound healing, however, varied among seals. Incision sites of the two seals that were implanted with the cylindrical IMP models remained clean and dry and healed within $10 \mathrm{~d}$ after surgery. Minimal postoperative swelling was observed in these two animals. However, wound breakdown was evident in both seals that were implanted with $16 \mathrm{M}$ $3 \mathrm{v}$ transmitters. Both animals had mucopurulent discharge from the wounds and opening of the skin incisions. The seal with the whip antenna had a marked leukocytosis and developed a large fluid pocket over the incision site, which was filled with mucopurulent exudate. Treatment included systemic antibiotic therapy and removal of superficial suture layers to allow for drainage and repeated irrigation of the surgical site with chlorhexidine solution (Vet Solutions ${ }^{\circledR}$, Inc., Fort Worth, TX). Incision sites eventually healed in both of these animals and the radio tags were not rejected. These observations indicated that wax-coated tags resulted in less tissue reaction than resin-encapsulated tags. However, due to the small sample size, other factors (e.g., possible contamination during or following surgery) may have been 
responsible for wound breakdown and cannot be discounted. The antenna of the BodyImp 16M-3v transmitter possibly exacerbated poor wound healing and it may not be appropriate for implantation in seals.

During the month of postoperative captive monitoring, another series of range tests were conducted for each transmitter. An overflight was conducted using a Cessna 182 high-winged aircraft (Ecoscan Survey, Freedom, CA) at an altitude of $\sim 825 \mathrm{~m}$ to determine the range of each transmitter from the air. Ranges were established for the transmitters while the seals were out of their pools by flying away from them, after having established an initial location. The ranges of the two IMP transmitters differed by approximately $4 \mathrm{~km}$, whereas ranges of the $16 \mathrm{M}-3 \mathrm{v}$ 's were practically identical (Table 1). Another "line of sight" range on land was established for each transmitter while seals were en route to their release destination. Reception distance of the transmitters did not appear to decrease after implantation, possibly indicating VHF radio signals were not greatly attenuated by the blubber and skin layers. Differences in $\mathrm{dB}$ output, battery size, body impedance, and other unknown factors probably attributed to variability in the different ranges of the transmitters (Telonics Inc., personal communication). The range of the bodylmp $16 \mathrm{M}-3 \mathrm{v}$ transmitter probably decreased after implantation as a result of the whip antenna coiling back up around the transmitter, which was detected from radiographs.

Pups were released at Bolinas Lagoon and Elkhorn Slough, California (Table 2) and three aerial surveys were conducted between the two locations from October to December. Two of the four harbor seals died $\sim 1$ and 15 wk after release, respectively. Post-mortem examination indicated that mortality probably was not a result of the implanted transmitters. Although histopathology was not performed for either animal because both carcasses were fairly decomposed, gross postmortem lesions and field observations indicated that the two seals may have been killed by a sea otter. Interestingly, the resin encased transmitter remained free-floating at the site of implantation, whereas tissue adhered to the wax coated transmitter.

Survey results and clinical observations (i.e., wound healing, blood parameters, and behavior) indicated the IMP/300/L model was most applicable for radiotracking seals. Therefore, six additional rehabilitated seals $(n=5$ weaned pups and 1 adult) were surgically implanted with this model during 2001 using a similar procedure as that detailed above. These seals were anesthetized by administering $0.8 \mathrm{mg} / \mathrm{kg}$ of Telazol intravenously and staples (Visistat, Weck Closure Systems ${ }^{\mathrm{TM}}$, Research Triangle Park, NC) were used to close the skin incisions. Surgery (i.e., time from anesthesia to extubation) averaged $77 \pm 16 \mathrm{~min}(\mathrm{SD})$ and implantation (i.e., time from incision to completion of sutures) averaged $35 \pm 9 \mathrm{~min}$ for both years.

Staples, removed 9-14 d after surgery, appeared to result in less tissue reaction than sutures. All seals resumed feeding within $24 \mathrm{~h}$ and clinical signs, CBCs, and serum biochemistry values were within clinically normal ranges within 1 wk after surgery. Skin incisions, which remained clean and dry, healed rapidly. Pups were released at Pebble Beach, California from 24 June to 15 August 2001 (range = 15-101 d after surgery), whereas the adult was retained for further treatment and 
then transferred to Long Marine Laboratory (LML), University of California at Santa Cruz, for a feeding experiment. Another range test indicated that ranges (i.e., $16.5,8.3$, and $7.4 \mathrm{~km}$ off the wing, nose, and tail of the aircraft, respectively) for the IMP/300/L transmitter implanted in that seal were slightly greater than those established for that same model while the seals were housed at TMMC. The seal was released on 4 November 2001 (38 wk after surgery) at Elkhorn Slough.

To determine whether surgical procedures could be applied successfully in the field, transmitters were implanted in five wild harbor seals that were captured using methods of Jeffries et al. (1993) in Elkhorn Slough (Table 2). Surgical procedures were conducted in a sterile field created at the Marine Operations building, Moss Landing Marine Laboratories (MLML). Staples were not applied to the incision site because they were not conducive to removal in the field. Total time of surgery averaged $73 \pm 11 \mathrm{~min}$. After surgery, seals were maintained in kennels for approximately $30 \mathrm{~min}$ and examined for any potential deleterious effects of anesthesia before release.

To locate implanted seals, aerial surveys were conducted semimonthly (weather permitring) along the California coastline as far north as Humboldt Bay and as far south as Point Conception. Two state-wide surveys from the northern California border to Imperial Beach, San Diego County, including the Channel Islands, were conducted during November 2002 and October-November 2003. The speed of aerial surveys was reduced to $170-185 \mathrm{~km} / \mathrm{h}$ from $250 \mathrm{~km} / \mathrm{h}$ to compensate for the decreased pulse rates and ranges of the implants. Occasional range tests conducted during aerial surveys resulted in estimates that were similar to those obtained for the IMP/300/L model while the seals were in captivity at TMMC. For example, the ranges found for one seal (\#180) while at sea were $11.6,5.6$, and $6.4 \mathrm{~km}$ off the wing, nose, and tail of the aircraft, respectively.

One carcass was collected on 9 January 2002 and upon post-mortem there did not appear to be any deleterious effects at the site of implantation. Another seal was recaptured 13 March 2003 during a subsequent tagging study in Elkhorn Slough. The animal appeared healthy and serum chemistry values were all within clinically normal ranges. During aerial surveys, $16(29 \%)$ data points were obtained for seals at sea, whereas $40(71 \%)$ were obtained for seals hauled out. Most fixes were for seals that appeared to reside in Elkhorn Slough. The longest period between tag implantation and seal relocation was $\sim 26$ mo (Table 2).

Our results indicate that implantation of subcutaneous radio transmitters in harbor seals is possible and that implants do not appear to reduce survival. Although problems associated with range limitations, permanent dispersal, unknown mortality, and transmitter failure still remain an issue with the use of subcutaneous transmitters, some of the other aforementioned problems (i.e., transmitter detachment and difficulties with long-term data acquisition) may be alleviated by using implants in future research. Overall, the utility of subcutaneous transmitters appears to be promising for studying long-term survival rates (i.e., to $3 \mathrm{yr}$ of age) and movements of harbor seals and presumably other pinnipeds. 


\section{ACKNOWLEDGMENTS}

We thank Bob VanWagenen of Ecoscan Surveys for his assistance with overflights, Michael Murray of the Monterey Bay Aquarium for his valuable advice, the entire staff of The Marine Mammal Center, and the MLML tagging team. Thanks to Gail Blundell, Bruce Heath, Steve Jeffries, and two anonymous reviewers for providing comments on this manuscript. This project was supported in part by the California Department of Fish and Game's Oil Spill Response Trust Fund through the Oiled Wildlife Care Network at the Wildlife Health Center, School of Veterinary Medicine, University of California, Davis. Additional funding was provided by The Marine Mammal Center, and additional support was received from the National Marine Mammal Labotatory and the Washington Cooperative Fish and Wildlife Research Unit, University of Washington. This study was approved by the San Jose State University Institutional Animal Care and Use Committee (Program \#785) and conducted under federal permit \#555-1565.

\section{Literature Cited}

Bengtson, J. L. 1993. Telemetry and electronic technology. Pages 119-139 in R. M. Laws, ed. Antarctic seals, Research Methods and Techniques. Cambridge University Press, Cambridge, U.K.

Bossart, G. D., T. H. Reidarson, L. A. Difrauf, and D. A. Duffieid. 2001. Clinical pathology. Pages 383-436 in L. A. Dierauf and F. M. D. Gulland, eds. Marine mammal medicine. 2nd edition. CRC Press Inc., Boca Raton, FL.

Eagle, T. C., J. Choromanski-Norris and V. B. KueChie. 1984. Implanting radio transmitters in mink and Franklin's ground squirrels. Wildlife Society Bulletin 12:180-184.

Fedak, M. A., M. R. Pullen and J. Kanwisher. 1983. Attachment of a radio tag to the fur of seals. Journal of Zoology, London 200:298-300.

Garshelis, D. L., AND D. B. SiNIFF. 1983. Evaluation of radio-transmitter attachment for sea otters. Wildlife Society Bulletin 11:378-383.

Haulena, M., AND R. B. Heath. 2001. Marine mammal anesthesia. Pages 655-688 in L. A. Dierauf and F. M. D. Gulland, eds. Marine mammal medicine. 2nd edition. CRC Press Inc., Boca Raton, FL.

Hernandez-Divers, S. M., G. V. Kollias, N. Abou-Madi and B. K. Hartur. 2001. Surgical technique for intra-abdominal radio transmitter placement in North American river otters (Lontra Canadensis). Journal of Zoo and Wildlife Medicine 32:202-205.

HoOver, J. P. 1984. Surgical implantation of radio telemetry devices in American river otters. Journal of American Veterinary Medical Association 185:1317-1320.

JefFries, S. J., R. F. Brown AND J. T. HARVEY. 1993. Techniques for capturing, handling and marking harbour seals. Aquatic Mammals 19:21-25.

Johnson, S. A., AND K. A. Berkiey. 1999. Restoring river otters in Indiana. Wildlife Society Bulletin 27:419-428.

lander, M. E., J. T. Harvey and F. M. D. Gulland. 2003. Hematology and serum chemistry comparisons between free-ranging and rehabilitated harbor seal (Phoca vitulina richardsi) pups. Journal of Wildlife Diseases 39:600-609.

Mulcahy, D. M., AND G. Garner. 1999. Subcutaneous implantation of satellite transmitters with percutaneous antennae into male polar bears (Ursus maritimus). Journal of Zoo and Wildlife Medicine 30:510-515.

Petersen, M. R., D. C. Douglas and D. M. Mulcahy. 1995. Use of implanted satellite transmitters to locate spectacled eiders at sea. Condor 97:276-278.

Ralls, K., D. B. SinifF, T. D. Williams and V. B. KueChle. 1989. An intraperitoneal radio transmitter for sea otters. Marine Mammal Science 5:376-381.

Reid, D. G., W. E. Melquist, J. D. Woolington and J. M. Noll. 1986. Reproductive 
effects of intraperitoneal transmitter implants in river otters. Journal of Wildlife Management 50:92-94.

Spelman, L. H., W. J. Jochem, P. W. Sumner, D. P. Redmond and M. K. Stoskopf. 1997. Post anesthetic monitoring of core body temperature using telemetry in North American river otters (Lutra canadensis). Journal of Zoo and Wildlife Medicine 28:413417.

Stoskopf, M. K., L. H. Spelman, P. W. Sumner, D. P. Redmond, W. J. Jochem, and J. F. LeVINE. 1997. The impact of water temperature on core body temperature of North American river otters (Lutra canadensis) during simulated oil spill recovery washing protocols. Journal of Zoo and Wildlife Medicine 28:407-412.

WILLIAMS, T. D., AND D. B. SinIFF. 1983. Surgical implantation of radio telemetry devices in the sea otter. Journal of American Veterinary Medical Association 183:1290-1291.

Received: 23 December 2003

Accepted: 16 June 2004 